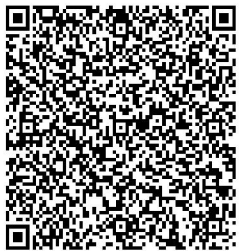

\title{
ECOTOURISM FOR RURAL KARNATAKA: SOME IMPACT ASSESSMENTS
}

\author{
Nanjunda D.C*
}

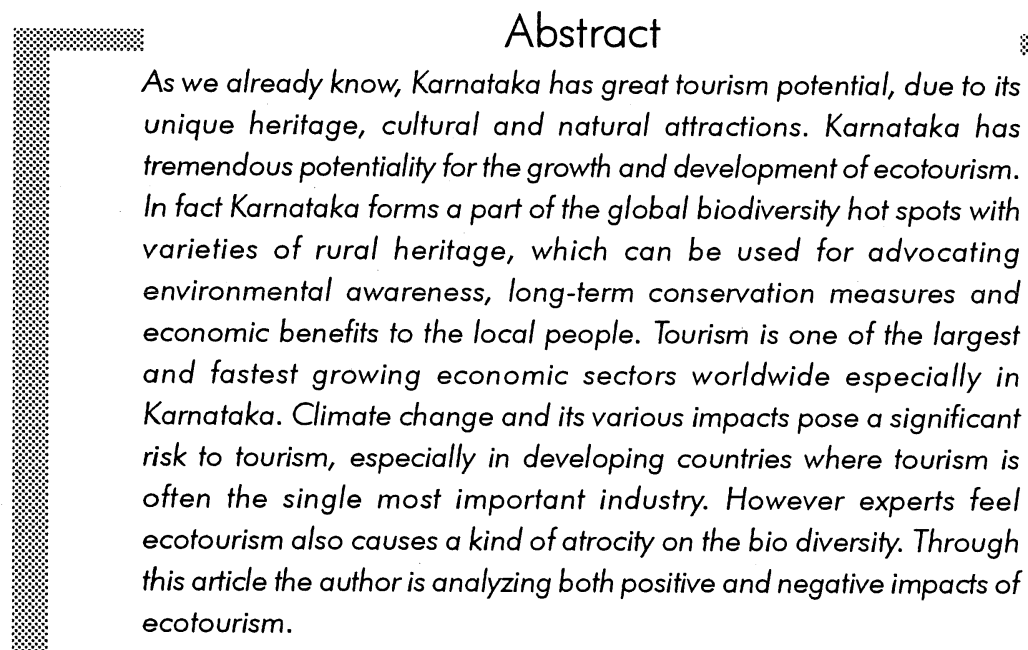

* Project Director, Center for Advanced Rural and Tribal Policy Innovation and Management Kushal Nager-34, Kodagu Dist, Karnataka-India. 


\section{Introduction}

A Mexican environmentalist Hector Ceballos lacscurain in 1983 first coined the term ecotourism. The concept has however, developed in to a scientific approach to the planning, management of tourism products and activities. Ecotourism signifies the tourist's interest in the customs of the indigenous and exotic people. It is a form of special interest tourism as different from general tourism, as it forces directly on the local people. Ecotourism is community based, participatory and is designed to improve the economic and social well being of local villagers in addition to the concern for institutional and physical environment.

Tourism is the largest and fastest growing economic sectors worldwide. Climatic change and its various impacts pose a significant risk to tourism, especially in developing countries where tourism is often the single most important industry. Climatic changes will have an impact on tourism, the marine and terrestrial biodiversity, and as a consequence on the livelihoods of local communities. Globally, the tourism sector will have to face the risks of climatic changes, contribute to mitigation of greenhouse emissions, and adapt to unavoidable impacts through careful management of the natural and other resources on which the sector relies. Among all tourist destinations, Small Island Developing States (SIDS) and coastal zones are most vulnerable and many are already experiencing impacts consistent with the climate change. Understanding vulnerabilities, managing risks, building capacity, and implementing adaptation policies and measures are therefore urgently needed in SIDS and will achieve the greatest immediate benefit within the whole tourism sector. Specific programmes and demonstration activities in many states of our countries are proposed to implement adaptation measures and thereby achieve both short and long-term local benefits in these highly vulnerable destinations.

The UN assembly has recognized the global importance of ecotourism and its benefits as well as its impact with the launching of the Year 2002 as the International year of ecotourism. This offers opportunities to review ecotourism experiences world wide, in order to consolidate tools and institutional framework that ensures suitability in future. This means maximizing the economic; environment and social benefits from ecotourism. For many states and countries, ecotourism offers an opportunity to add value to their traditional forms of tourism. Ecotourism is already the largest source of foreign exchange to some of the countries. The geographical diversity of Karnataka is a wealth of the ecosystem, which is well protected and well preserved. These ecosystem have become the major ecotourism resource include Biosphere's, Mangroves forests, Coral reefs, Deserts, Mountain, flora and fauna and water resources etc. 
The International Ecotourism Society defines Ecotourism as: "responsible travel to natural areas that conserves the environment and improves the welfare of local people". The Australian Commission on National Ecotourism Strategy calls it: "nature-based tourism that involves education and interpretation of the natural environment and is managed to be ecologically sustainable". Since the publication of her excellent book "Ecotourism and Sustainable Development" Martha Honey's definition is quickly becoming the standard. Most serious studies of ecotourism including several University programs now use this as the working definition.

\section{Characteristics of Ecotourism}

\section{1) Involves travel to natural destinations}

2) Minimizes Impact. Tourism causes damage. Ecotourism strives to minimize the adverse effects of hotels, trails, and other infrastructure by using either recycled materials or plentifully available local building materials, renewable sources of energy, recycling and safe disposal of waste and garbage, and environmentally and culturally sensitive architectural design.

3) Builds environmental awareness. Ecotourism means education, for both tourists and residents of nearby communities. Well before departure tour operators should supply travelers with reading material about the country, environment and local people, as well as a code of conduct for both the traveler and the industry itself. This information helps prepare the tourist as The Ecotourism Societies guidelines as stated "to learn about the places and peoples visited" and "to minimize their negative impacts while visiting sensitive environments and cultures". Essentials to good ecotourism are well-trained, multilingual naturalist guides with skills in natural and cultural history, environmental interpretation, ethical principles and effective communication. Ecotourism projects should also help educate members of the surrounding community, schoolchildren and the broader public in the host country.

4) Provides direct financial benefits for conservation: Ecotourism helps raise funds for environmental protection, research and education through a variety of mechanisms, including park entrance fees, tour company, hotel, airline and airport taxes and voluntary contributions.

5) Provides financial benefits and empowerment for local people: National Parks and other conservation areas will only survive if there are "happy people" around their parameters. The local community must be involved and should receive income and other tangible benefits (potable water, roads, health clinics, etc.) from the conservation area and it's tourist facilities. More importantly, if Ecotourism is to 
be viewed as a tool for rural development, it must also help shift economic and political control to the local community, village, cooperative, or entrepreneur.

6) Respects local culture: Ecotourism is not only "greener" but also less culturally intrusive and exploitative than conventional tourism. Whereas prostitution, black markets and drugs are often the by-products of mass tourism, ecotourism strives to be culturally respectful and have a minimal effect on both the natural environment and the human population of a host country. This is not easy, especially since ecotourism often involves travel to remote areas where small and isolate communities have had little experience interacting with foreigners. And like conventional tourism, ecotourism involves an unequal relationship of power between the visitor and the host and a commodification of the relationship through exchange of money.

7) Supports human rights and democratic movements: Although tourism is often globally hailed as a tool for building international understanding and world peace, this does not happen automatically; in fact tourism bolsters the economies of repressive and undemocratic states. Mass tourism pays scant attention to the political system of the host country or struggles within it, unless civil unrest spills over into attacks on tourists. Ecotourism demands a more holistic approach to travel, one in which participants strive to respect, learn about and benefit both the local environment and local communities. Although not part of The Ecotourism Societies definition, giving economic benefits and showing cultural sensitivities to local communities cannot be separated from understanding their political circumstances. In many developing countries, rural populations living around national parks and other ecotourism attractions are locked in contests with the national government and multinational corporations for control of the assets and their benefits. Determining whether to boycott or visit a country is not always easy. Among the questions to ask are: Does the economic growth fueled by tourism really improve the chances of human rights being respected? Will boycotting country harm already impoverish workers more than it will corporate or government titans?

\section{Baseline - Current State of Environmental System}

Karnataka's biodiversity and ecosystems, particularly marine and coastal, are at considerable risk due to the climate change, while at the same time they are of critical importance to the tourism industry. The Karnataka Government drafted a National Biodiversity Strategy Action Plan (NBSAP) in 1999 to meet Karnataka's obligations under the international Convention on Biological Diversity, and demonstrates its commitment to preserving the country's biodiversity. This plan does not mention climate change, but focuses on the risks to coral reefs from salinity changes and sedimentation due to flooding and cyclones. The Plan recognizes 
impacts on biodiversity from coastal development, including seawalls, land reclamation, dredging, and ports, and sedimentation due to clearing of land for agriculture. Extensive destruction of mangroves is taking place due to coastal development, including the tourism purposes and remaining mangroves suffer from solid waste pollution and industrial dumping. Karnataka is part of 6 projects under the GEF Enabling Activity for the preparation of National Biodiversity Strategy Action Plans. The biodiversity aspects of this project will link with those activities; as well as with projects carried out by the University of the South Pacific (e.g. Integrated Coastal Management). The Karnataka Ministry of Tourism is highly committed to the sustainable development of tourism, as is manifested in its Karnataka ecotourism and Village-Based Tourism Policy \& Strategy. The Ministry maintains a Sustainable Tourism Development section and recently appointed 3 'sustainable development tourism officers'. Sustainable tourism is also mentioned in the Karnataka Islands Visitors Bureau Act 2004 stating: 'The object of the Bureau is to ensure that the Karnataka Islands is promoted and marketed as a tourist destination for the purpose of maximizing sustainable and long-term benefits to the Karnataka Islands'. Recently, the Ministry of Tourism and WWF South Pacific undertook a 'strategic environmental assessment' (SEA) of Karnataka's Tourism Development Plan (1998-2005), which is now incorporated in the next development plan. The Karnataka Government through the Department of Environment is currently developing a Climate Change Policy, for which they sought input from different stakeholders, among others the Ministry of Tourism.

\section{Tourism Adaptation to Climate Change}

Climate has an impacts on tourism both directly and indirectly. In the beach tourism segment, which is so important to tourism in Karnataka, climate is a key attraction: tourists are attracted by sunshine, warm temperatures and little precipitation. Changes to the current climatic conditions, such as hotter temperature or wetter climate, could have an impact on Karnataka's attractiveness as a destination. One potential pathway lies in product diversification, already attempted by the Karnataka Visitor Bureau through the marketing of sports events, special interest and conference tourism. Tourists to Karnataka are also increasingly interested in the natural environment, especially marine ecosystems and the hinterland (ecotourism projects in inland communities), and a growing number of products cater for tourists who seek diversity beyond traditional beach holidays. Currently, tourists seem not to be deterred by hot temperatures or the perceived risk of cyclones; however, most tourists are aware of potential climate change impacts on Karnataka (Kumar, 2004). Risk management for climate change and tourism will need to take into account the wellbeing and health of both tourists and local communities. The Karnataka tourism industry also faces major issues resulting from climate change, such as shoreline 
and beach erosion (with a resulting need for beach nourishment), temporarily reduced water availability, interrupted supply chain (e.g. electricity), coral bleaching, and physical damage to property e.g. from sea surges (Becken, 2004). Damage to existing tourism infrastructure and local businesses is a major economic problem, especially for those located in highly vulnerable coastal areas. Ahmed (2003) pointed out that one major impediment for further tourism development in Karnataka is the lack of capital and investment. Climate-change-related hazards, such as cyclones increasing in its frequency or intensity, have the potential to substantially reduce existing tourism income and severely undermine efforts to attract new investment from within Karnataka and overseas. Becken (2004) identified the following barriers to climate change adaptation in Karnataka:

\section{Tourism and Natural Resource Management in the Context of Climate Change}

Indirectly, climate change can have a significant impact on tourism activities by altering the natural environment. There are two globally important Eco-Regions (see WWF) in Karnataka: the South Asian Forests and the Karnataka Barrier Reef. The coral reefs, in particular, are a major attraction for tourists, and the bleaching events in 2000 highlighted the vulnerability of those reefs to any changes in environmental conditions. Coral reefs are not only economically important to Karnataka in terms of the ecosystem services they provide, as they also represent strategic natural offshore sea-defense acting to buffer shorelines from wave action and other oceanic forces. The coral reefs also show how tourism, when poorly managed, can impact considerably on marine ecosystems. Inadequate sewage treatment, overuse of diving spots, and cutting back of mangroves for tourist development have led to a severe deterioration of reefs and marine life in a number of places in Karnataka. The tourism industry, along with governments and local communities, has a vested interest in conserving and enhancing the natural resource bases of Karnataka and the adjacent international waters, including protecting the existing high levels of biodiversity. Tourism can be a powerful ally for nature conservation, by generating much needed revenues for the maintenance of natural areas and reserves and through environmental education and awareness for both the local population and tourists.

\section{Livelihoods and Development Benefits}

In Karnataka, there is a strong interdependence between the climate, tourism and socio-economic developments. Recent development trends (e.g. population growth and density in coastal areas) in Karnataka have in many instances increased the 
vulnerability of Karnataka's ecosystems, economy, and its people to future climate and sea-level changes. Karnataka is highly dependent on tourism as a source of foreign exchange, employment, and contribution to GDP (30\% in total). Impacts on the tourism sector will automatically affect the Karnataka people. Tourism, through its multiplier effect, has great potential to provide socio-economic benefits for wider local economies, involving sectors such as agriculture, manufacturing and handicrafts. More recently, much emphasis has been placed on tourism development in more remote islands, mainly to improve livelihoods in those economically less developed areas. Tourism, if adequately planned and managed, can bring improved standards of infrastructure, health and education; food security; gender equality, personal safety, and self- esteem; improved natural resources and their management; and participation in policy making and planning. Above all, tourism can be an effective tool to reduce poverty in island communities. Several initiatives in the area of eco-tourism and community-based tourism have already started in Karnataka.

\section{Achieving National Sustainable Development Goals}

Tourism is recognized as being an effective tool in the reduction of poverty and a driver for socio-economic development, and it forms an integrated part of the Action Plan adopted at the World Summit on Sustainable Development in Johannesburg in order to achieve the Millennium Development Goals. The implementation of practical adaptation strategies that protect the tourism assets and resources required for its sustainability from the impacts of climate change is vital for Karnataka. The development and implementation of pragmatic integrated coastal zone management and water resources management systems, along with preventative measures, planning and preparedness for disasters relating to climate change, and contingency plans for extreme weather events are also key to ensuring national sustainable development goals. The project will take into account relevant national documents and plans relating to sustainable development including fragile ecosystems, the agricultural sector, infrastructure development and land management; all issues of great importance to tourism in Karnataka and the communities that rely upon the existence of tourism.

In order to alleviate the barriers to sustainable development, capacity building, coastal rehabilitation strategies and resilience building activities needs to be established and implemented as a matter of urgency. The mainstreaming of climate change into coastal adaptation strategies is also required as are the further development and implementation of coastal planning toolkits, integrated coastal zone management strategies and the analysis of the socio-economic impacts of coastal degradation and rehabilitation. 
Tourism is one of the largest and fastest growing economic sectors worldwide. Climate change and its various impacts pose a significant risk to tourism, especially in developing countries where tourism is often the single most important industry. Climate change will impact on tourism, the marine and terrestrial biodiversity, and as a consequence on the livelihoods of local communities. Globally, the tourism sector will have to face the risks of climate change, contribute to mitigation of greenhouse emissions, and adapt to unavoidable impacts through careful management of the natural and other resources on which the sector relies. Among all tourist destinations, Small Island Developing States (SIDS) and coastal zones are most vulnerable and many are already experiencing impacts consistent with climate change. Understanding vulnerabilities, managing risks, building capacity, and implementing adaptation policies and measures is therefore urgently needed in SIDS and will achieve the greatest immediate benefit within the whole tourism sector. Specific programmes and demonstration activities in three countries (Karnataka, the Maldives and the Seychelles) are proposed to implement adaptive measures and thereby achieve both short- and long-term local benefits in these highly vulnerable destinations. However, the overall project - the synthesis of the three country studies - goes well beyond generating local benefits. The country studies will be critical to improve our wider understanding of climate change impacts on tourism, including adaptation opportunities in other island destinations, coastal zones, and for tourism worldwide. This enhanced capacity of tourism to adapt to climate change, and to manage natural resources in a more sustainable manner, will generate substantial global environmental benefits, especially in the area of biodiversity and natural resource management (e.g. water resources). Based on the governments' requests, the World Tourism Organization (WTO) has been coordinating with the Ministries of Tourism of Karnataka, the Seychelles, and the Maldives, to implement three demonstration country projects on climate change adaptation in the tourism sector. The proposed national-, sector- and communityscale demonstration projects will have high replicability and upscaling potential. Thus the experiences generated and lessons learned by these three SIDS can be applied at other island and coastal tourism destinations. The three SIDS seeking to demonstrate tourism adaptation have a number of commonalties, but also many distinctive environmental and socioeconomic characteristics.

The aim of this project is to further develop and demonstrate adaptation initiatives that will reduce the vulnerability of the tourism sector, and its natural and human resource base, to the impacts of climate variability and change, and in doing so enhance the sustainability of the natural resources and the quality of life of the people of Karnataka and also generate global environmental benefits. A specific focus of the project is to build and utilize the capacity of Karnataka to integrate responses to concerns related to climate variability and change into a broader risk 
management framework, strategy and plan for the tourism sector. The project will build on previous studies linking climate change, biodiversity, human livelihoods and tourism. Finally ecotourism is based on the four guiding principles-nature orientation eco-sustainability, possibility of conducting research and involvement of local people. Modern tourism industry may take different forms including adventures, health trade fairs, and cultural religious festivals, national celebration and food festivals. The time has come when we must concentrate on the potential of rural tourism in Karnataka. It is rural tourism development; which it may prove to be the backbone of Karnataka's rural economy.

\section{Environmentally Risky}

Ecotourism may sound benign, but one of its most serious impacts is the exploitation of' virgin' territories - national parks, wildlife parks and other wilderness areas which are packaged for ecotourists as the green option. Ecotourism is highly consumer-centered, catering mostly to urbanized societies and the new middleclass 'alternative lifestyles'. Mega-resorts, including luxury hotels, condominiums, shopping centers and golf course, are increasingly established in nature reserves in the name of ecotourism - in many cases protested as 'ecoterrorism'. Such projects build completely artificial landscapes, tending to irretrievably wipe out plant and wildlife species - even entire eco-systems.

\section{No Local Benefits}

Diverse local social and economic activities are replaced by an ecotourism mono culture. Contrary to claims, local people do not necessarily benefit from ecotourism. Tourism-related employment is greatly overrated: locals are usually left with lowpaying service jobs such as tour guides, porters, and food and souvenir vendors. Most money, as with conventional tourism, is made by foreign airlines, tourism operators, and developers who repatriate profit to their own economically more advanced countries.

Ecotourism's claim that it preserves and enhances local cultures is highly insincere. The simultaneous romanticism and devastation of indigenous cultures is one of ecotourism's ironies. Given a lack of success stories, and sufficient evidence of serious adverse effects, the current huge investments in ecotourism are misplaced and irresponsible. Research, education, and information for tourists are needed, and the countering of ecotourism's demeaning of local cultures.

Ecotourism covers all those aspects of travel whereby people learn about each other's ways of life and thought. It is a form of special interest tourism as different 
from general tourism, as it focuses directly on the local people. Ecotourism is community based, participatory and designed to improve the economic and social well being of local villagers in addition to the concerned institutional and physical environment.

Truly speaking the total benefit of ecotourism should go to the local community. Moreover, the local community needs to ensure that this kind of tourism will help in the way of sustainable development and not mere of minting money for Government and private people. Community based participation means the launching of ecotourism programmes, which takes place under the control and with the active participation of the local people who inhabit that place of natural attraction for outsiders. Ecotourism also should help to revive the local people's interest and pride in their cultural, traditions and values. Rural tourism also provides ample opportunities to study religious and ritualistic services. Festivals, religious rituals and public performances provide inputs to symbolic qualities of rural tourism.

Tourism has now become a key area affecting all aspects of a nation life. Govt must take appropriate measures for creating a suitable framework for the promotion and development of rural tourism. Tourism sector is fast expanding and becoming highly diversified units of supply. Increased tourist traffic among the counters calls for new marketing, promotional and pricing policies. Resource conservation, utilization and balanced development activities require and financial and technical resources are also required for successful promotional and development strategy in rural tourism.

Karnataka's biodiversity and ecosystems, particularly marine and coastal, are at considerable risk due to climate change, while at the same time they are of critical importance to the tourism industry as well as for protection against climate impacts. Finally ecotourism is based on the four guiding principles-nature orientation eco sustainability, possibility of conducting research and involvement of local people. Modern tourism industry may take different forms including adventures, health trade fairs, and cultural religious festivals. National celebration and food festivals. Among these ecotourism blends a different strategy of enjoying the natures serenity in its own way. The time has come when we must concentrate on the potential of rural tourism in Karnataka. It is rural tourism development; it may prove to be the backbone of Karnataka's rural economy. 


\section{References}

- Gupta 2001 Ecotourism for Rural Economy: A Review Prospective. Man and Ecology 23 (3): 23-34.

- Sharma and Ananda 2004 Biodiversity and Tourism, Kalplaz Publication: New Delhi.

- Sheaker 1991 Understanding the Relationship Between Tourism, the Environment, and Sustainable Development. Tourism Research. Hull Publication: Quebec.

- Zoladeski, C.A. G.M. Wickware, R.J. Delorme 2002 Ecotourism for Development Journal of Tourism Studies, Vol 23 No 5. 